La comparaison des chromosomes $X$ permet de supposer qu'ils ont une origine commune et deux remaniements chromosomiques permettent de passer de l'un à l'autre.

De nombreuses formes intermédiaires ont dû exister entre les deux espèces actuelles, mais les possibilités d'hybridation montrent que les remaniements chromosomiques ont eu un rôle cloisonnant relativement modéré.

\title{
Essai de phylogénie chez quelques actiodactyles à partir des bandes $R$
}

\author{
M. THERET, J. FROGET, M. FRANCK et M. C. NAIN
}

\author{
École Nationale Vétérinaire de Lyon, 2, quai Chaveau, 69ooo Lyon, France
}

Les chromosomes de bovins et de caprins, dénaturés par la méthode des bandes $R$, présentent une grande similitude, au plan de leur nombre et de leur structure; il s'agit de 28 paires d'autosomes télocentriques. La différence la plus marquante entre les deux caryotypes concerne le chromosome $\mathbf{X}$ des caprins, qui est télocentrique, alors que celui des bovins est submétacentrique. En outre, les chromosomes : II, I $4,18,25,26,28$, et l'Y, sont très légèrement différents d'une espèce à l'autre.

Les chromosomes de l'espèce ovine sont au nombre de 54. Trois paires d'autosomes submétacentriques résulteraient de la fusion centrique entre les chromosomes I et 4,2 et 8,5 et 9 . Le caryotype de l'espèce ovine, pour les autres chromosomes, est très proche de celui de l'espèce caprine.

Ovis aries, ovis musimon et leur hybride, ne présentent pas de différences marquantes quant à leur caryotype.

\section{Chromosomal studies on Cultured Fetal Fluid Cells collected by Transsacrostiatic Amniocentesis from Heifers during the Third Month of Pregnancy}

\author{
E. I. SINGH, M. D. EAGLESOME, W. C. D. HARE and D. MITCHELL (*)
}

\author{
Animal Pathology Division, Health of Animals Branch, \\ Agricultuve Canada, Animal Diseases Research Institute (E), \\ Box II 300 , Station $H$, Ottawa, Ontario, Canada, $\mathrm{Kz} \mathrm{H} 8 \mathrm{P9}$ \\ $\left(^{*}\right)$ Animal Diseases Research Institute (W) P.O. Box 640, Lethbridge, Alberta, Canada TIJ $3 Z_{4}$
}

Attempts were made to collect fetal fluids from 37 pregnancies in 34 heifers during the third month of pregnancy by inserting an aspirating needle through the sacrosciatic ligament and uterine wall into the fetal sac.

In ro trial attempts, six samples were collected and the cells set up in culture; four cases of fetal death occurred. Subsequently, in 27 test attempts, cells from 23 of 25 samples collected were set up in culture; three cases of fetal death occurred. Eleven cell cultures were also set up from fluids obtained from slaughterhouse material.

Sufficient growth for chromosomal analysis was obtained from 28 of 40 cultures. Anatomical confirmation of sex was made in 23 of these. Confirmation was not possible in three cases due to absorption or maceration of the fetus, but the chromosomal sex of one of these was male and, therefore, had to be correct. The sex of the other two cases was predicted to be female and found to be male.

Contamination of fetal fluid samples by maternal cells was a constant possibility which could lead to the misinterpretation of results. To minimize this, the first $\mathrm{I}-2 \mathrm{ml}$ of fetal fluids aspirated were discarded, multiple cultures were set up from each sample and, when male cells were not observed, numerous metaphase spreads from several passages of each culture were studied.

Twelve cultures failed due to incubator failure, bacterial or fungal contamination, or too few culturable cells. 